\title{
Influence of Debittered Lemon Rind on Quality of Lemon Flavoured Paneer
}

\author{
R. Yashavantha, Suneeta Pinto*, Dasharath Patel, Preeti Paul and Mamata Chaudhary
}

SMC College of Dairy Science, Anand Agricultural University, Anand, India

*Corresponding author

\begin{abstract}
A B S T R A C T
\section{Keywords}

Paneer, Lemon rind, Debittering, Zinc sulphate, $\beta$ cyclodextrin

Article Info

Accepted:

12 August 2020

Available Online:

10 September 2020

Three batches of lemon flavoured paneer was prepared from standardized milk $(4.5 \%$ fat/8.5 \% MSNF).Three forms of lemon rind were tested for their suitability for use in lemon flavoured paneer (LFP) viz. shreds, paste and powder. Sensory evaluation revealed that total score of sample containing shreds was significantly $(\mathrm{P}<0.05)$ higher compared the other two forms. Two debittering agent viz. $\mathrm{ZnSO}_{4}$ and $\beta$-cyclodextrin were evaluated for their efficacy in reducing bitterness of lemon rinds. Five batches of paneer containing lemon rind shreds treated with different levels of debittering agents viz. D0 (no debittering agent), D1 ( $\mathrm{ZnSO}_{4} 20 \mathrm{mg} / 100 \mathrm{ml}$ of water and $\beta$-cyclodextrin $330 \mathrm{mg} / 100 \mathrm{ml}$ of water), D2 $\left(\mathrm{ZnSO}_{4} 30 \mathrm{mg} / 100 \mathrm{ml}\right.$ of water and $\beta$-cyclodextrin $300 \mathrm{mg} / 100 \mathrm{ml}$ of water), D3 ( $\mathrm{ZnSO}_{4} 40$ $\mathrm{mg} / 100 \mathrm{ml}$ of water and $\beta$-cyclodextrin $250 \mathrm{mg} / 100 \mathrm{ml}$ of water $), \mathrm{D} 4\left(\mathrm{ZnSO}_{4} 50 \mathrm{mg} / 100\right.$ $\mathrm{ml}$ of water and $\beta$-cyclodextrin $100 \mathrm{mg} / 100 \mathrm{ml}$ of water) were prepared. Debittered lemon shreds were incorporated @ $1.0 \%$ (w/w of milk) in all samples. It was found that type and level of debittering agents had significant effect $(\mathrm{P}<0.05)$ on moisture and FDM content of paneer. However no significant $(\mathrm{P}>0.05)$ effect was observed in other compositional attributes content of paneer. Treatment of lemon rind with $40 \mathrm{mg} \mathrm{ZnSO} / 100 \mathrm{ml}$ of water and $250 \mathrm{mg} \beta$-cyclodextrin $/ 100 \mathrm{ml}$ of water at D3 level resulted in significant reduction in bitterness of LFP.
\end{abstract}

\section{Introduction}

Paneer, an acid coagulated dairy product is an important indigenous, nutritious product, which is very rich in protein. It is also rich source of fat, minerals and vitamins. Paneer is used as a base for the preparation of a large number of culinary dishes. However paneer has a fairly bland flavour. The use of flavorings in food products dates back as early as the 1660s with consumption of lemonade and orangeade (Hargitt, 2006). Consumer demand for foods flavoured with natural ingredients has increased, whereas the safety aspect of chemical additives has been questioned.

Citrus limon L. belongs to family Rutaceae. The family of citrus fruits consists of Oranges, Kinnow, Khatta, Lime, Lemon, Grapefruit, Malta, Sweet orange etc. The most common variety grown in India is Kagzikalan lemon, which is characterized by its spherical, yellow, with apex slightly nippled, base rounded; rind thin, smooth, flesh acidic, light yellow, juicy, seedy (8-13 seeds).The large 
quantities of processed citrus fruits result in large amounts of by-products. The industrial utilization of these by-products was encountered before 1920 and has increased significantly since the 1980s (Dilas et al., 2009). Albedo is the major component of lemon rind and is a spongy and cellulosic layer laid under flavedo. The thickness of the albedo fluctuates according to several variables, among them variety and degree of ripeness. Albedo has high dietary fiber content and if added to new meat products permits to formulate healthier products like beef burgers and dry cured sausages (AlesonCarbonell et al., 2005). Furthermore, the presence of associated bioactive compounds (flavonoids and vitamin C) with antioxidant properties in fresh lemon albedo involves healthier benefits than other sources of dietary fiber (Aronson, 2001; Marin et al., 2002). Moreover, the lemon oil exhibit significant antimicrobial effect. One of the major components present in essential oil is limonen. Inspite of it health benefits, one of the major drawbacks for use of lemon rind in food products is its extremely bitter taste. Incorporation of lemon rind as a value added ingredient in paneer making resulted in a product which was extremely bitter and was found to be unacceptable to panellists which resulted in significant reduction in overall acceptability scores of paneer containing lemon rind.

It has been reported that low molecular weight compounds, such as zinc lactate and zinc sulphate, can significantly decrease the bitterness elicited by a range of bitterants including caffeine, quinine hydrochloride, tetralone, and denatonium benzoate (Keast and Breslin, 2005; Keast, 2003; Keast, 2008). $\beta$-cyclodextrin ( $\beta$ $\mathrm{CD}$ ) is also commonly used cyclodextrin for this purpose. Cyclodextrins have also been used as an additive to lemon and orange juice as they reduce the perceived bitterness of both naringin and limonin (Shaw, 1990).
Zinc is one of the most important trace elements present in the body with a great nutritional importance and that has a recognized action on more than 300 enzymes, participating in either their structure or in their catalytic and regulatory action (Salgueiro et al., 2002, Pomastowski et al., 2014). Through interaction with specific amino acids (serine, threonine) on the extracellular portion of some bitter taste receptors, $\mathrm{ZnSO}_{4}$ may alter the integrity of TAS2R receptors, preventing them from functioning normally (Keast, 2003). Zinc fortification of foods is an attractive and active strategy for decreasing zinc deficiency in the population and may confer additional value to the use of $\mathrm{ZnSO}_{4}$ in functional foods (Salgueiro et al., 2002).

Cyclodextrins are cyclic oligosaccharides derived enzymatically from starch hydrolysates. Cyclodextrins usually bind bitter molecules at a fixed stoichiometry, usually 1:1 (Tamamoto et al., 2010). Cyclodextrins were capable of partially suppressing the bitterness of soy protein, soy protein hydrosylates (Linde et al., 2010) and olive oil (Rescifina et al., 2010). In addition, $\beta-C D$ is nontoxic, edible, non-hygroscopic and chemically stable. Furthermore, in 1998 it was introduced into the Generally Recognized as Safe (GRAS) list of compounds, because it is not absorbed in the upper gastrointestinal tract, and it is completely metabolized by the colon microflora (Dias et al., 2010). Magnesium sulphate $\left(\mathrm{MgSO}_{4}\right)$ has been shown to decrease the bitterness of quinine hydrochloride by approximately $52 \%$ without affecting the perception of other basic taste qualities (Keast, 2003), thus providing support for its use to decrease the taste intensity of a wider range of bitter functional formulations compared with that of $\mathrm{ZnSO}_{4}$.

Hence, the present study was planned and conducted to assess the effect of selected 
debittering agents on acceptability of paneer incorporated with debittered lemon rind.

\section{Materials and Methods}

Fresh, raw mixed (cow and buffalo) whole milk was procured from Anubhav Dairy, and standardized by mixing required quantity of skim milk and cream. The average composition of milk was $4.6 \pm 0.05 \%$ fat and $8.6 \pm 0.05 \%$ MSNF. Citric acid, $\beta$ cyclodextrin and zinc sulphate were procured from Loba-Chemical Pvt. Ltd. D-limonen and orange oil were supplied by Hi-Media Laboratories Pvt. Ltd. Yellow coloured, Kagzi variety lemon were procured from local market, in Anand.

\section{Selection of lemon (size, sorting, trimming)}

Tender, firm lemons of round or oval shape and having yellowish to slightly greenish but uniform in colour were selected. The average weight of lemons ranged from 60to $75 \mathrm{~g}$. Over ripe, under ripe and defective lemons were screened out. The lemons were thoroughly cleaned to remove any dirt or insecticide residues.

The lemons were washed under a faucet with running potable water for one min. and then soaked in water containing 25 to $50 \mathrm{ppm}$ chlorine for $10 \mathrm{~min}$. During peeling, care was taken to use a sharp, clean, dry stainless steel peeler to prevent the discolouration of the plant tissues. Lemon rinds were immediately transferred in to a $5 \% \mathrm{NaCl}$ solution and kept for $1 \mathrm{~h}$ at $7 \pm 1{ }^{0} \mathrm{C}$. Quantity of peels obtained was 140 to $160 \mathrm{~g}$ per $\mathrm{kg}$ lemon and after soaking drained through muslin cloth, add pasteurized chilled water (4X) by weight of peel thereafter add zinc sulphate $(50 \mathrm{mg} /$ $100 \mathrm{ml}$ of water) and $\beta$-cyclodextrin $(200 \mathrm{mg} /$ $100 \mathrm{ml}$ of water) and keep it for overnight at $7 \pm 1{ }^{0} \mathrm{C}$ and draining to get processed lemon shreds (110-115 g). To obtain shreds, lemon rind was shredded in a clean and sanitized grater attachment of Boss Food Processor (Model - Boss Food Processor, Boss Electrical, Solan, Himachal Pradesh). The shreds had an average length of $0.8 \pm 0.1 \mathrm{~cm}$, average width and thickness of $0.3 \pm 0.1 \mathrm{~cm}$.

Lemon paste was prepared by washing of lemons thoroughly, cleaned to remove any dirt or insecticide residues. The lemons were washed under a faucet with running potable water for one min. and then soaked in water containing 25 to $50 \mathrm{ppm}$ chlorine for $10 \mathrm{~min}$. During peeling, care was taken to use a sharp, clean, dry stainless steel peeler to prevent the discolouration of the plant tissues. Lemon rinds were immediately transferred in to a 5 $\% \mathrm{NaCl}$ solution and kept for $1 \mathrm{~h}$ at $7 \pm 1{ }^{0} \mathrm{C}$ and draining and grinding to a fine paste (140-160 g). And later add zinc sulphate (50 $\mathrm{mg} / 100 \mathrm{ml}$ of water) and $\beta$-cyclodextrin (200 $\mathrm{mg} / 100 \mathrm{ml}$ of water) and keep it for overnight at $7 \pm 1{ }^{0} \mathrm{C}$ and processed lemon paste $(140-160 \mathrm{~g})$.

Lemon peel powder was prepared by washing of lemons thoroughly, cleaned to remove any dirt or insecticide residues. The lemons were washed under a faucet with running potable water for one min. and then soaked in water containing 25 to $50 \mathrm{ppm}$ chlorine for $10 \mathrm{~min}$. During peeling, care was taken to use a sharp, clean, dry stainless steel peeler to prevent the discolouration of the plant tissues.

Lemon rinds were immediately transferred in to a $5 \% \mathrm{NaCl}$ solution and kept for $1 \mathrm{~h}$ at $7 \pm 1$ ${ }^{0} \mathrm{C}$ and transferred into a freeze dryer (-30 to $50{ }^{0} \mathrm{C} / 8-10 \mathrm{~h}$ ) after freeze drying, grinding to get powder and add pasteurized chilled water (4X) by weight of peel thereafter add zinc sulphate $(50 \mathrm{mg} / 100 \mathrm{ml}$ of water $)$ and $\beta$ cyclodextrin $(200 \mathrm{mg} / 100 \mathrm{ml}$ of water) and keep it for overnight at $7 \pm 1{ }^{0} \mathrm{C}$ and draining to get processed lemon powder. 


\section{Debittering process}

In preliminary trials, lemon rind were treated with different levels of $\mathrm{ZnSO}_{4}$ viz. 50, 75, $100,125,150$ and $175 \mathrm{mg} / 100 \mathrm{ml}$ of water and $\beta$-cyclodextrin was added @ 150,175, 200, 225, 250 and $300 \mathrm{mg} / 100 \mathrm{ml}$ of water. Magnesium sulphate used at different levels $50,75,100,125,150$ and $175 \mathrm{mg} / 100 \mathrm{ml}$ of water viz. It was observed that use of $\mathrm{ZnSO}_{4}$ and $\beta$-cyclodextrin when used alone or in combination caused notable reduction of bitterness at all the levels of studied. Hencetwo debittering agents were evaluated for their efficacy in reducing bitterness when used in combination.

A $10 \%$ stock solution of $\mathrm{ZnSO}_{4}$ was prepared and $15 \%$ stock solution of $\beta$ - cyclodextrin was prepared separately. Four hundred $\mathrm{ml}$ pasteurized and cooled $\left(30-35^{\circ} \mathrm{C}\right)$ water in a $500 \mathrm{ml}$ beaker. Calculated quantity of stock solution of $\mathrm{ZnSO}_{4}(20$ to $50 \mathrm{mg} / 100 \mathrm{ml}$ of water) and $\beta$ - cyclodextrin (80 to $200 \mathrm{mg} / 100$ $\mathrm{ml}$ of water) was added to the beaker. One hundred $\mathrm{g}$ drained lemon rind was added to the beaker and mixed thoroughly. The proportion of drained lemon rind: water containing $\mathrm{ZnSO} 4$ and $\beta$ - cyclodextrin at selected levels was 1:4. The contents in the beaker were kept overnight at $7 \pm 1{ }^{0} \mathrm{C}$. The debittered rinds were then drained through a muslin cloth. The quantity of debittered lemon rind obtained was $80 \mathrm{~g}$ per $100 \mathrm{~g}$ rind.

\section{Method for manufacturing of lemon flavoured paneer}

Three $\mathrm{kg} \operatorname{milk}(4.5 \%$ fat/8.5 \%MSNF) was taken in a stainless steel vessel was heated to $90^{\circ} \mathrm{Cfor} 5 \mathrm{~min}$ and cooled to $80^{\circ} \mathrm{C}$. Processed lemon rind (shreds (@0.8\% \%/w of milk, paste @ 1.0 and powder @ 0.5\% w/w of milk) and the flavouring extracts (D-limonene and orange oil, 75:25) were added @ $1 \mathrm{ml} / \mathrm{kg}$ milkat this stage and stirred for one min. The milk was coagulated with citric acid $(1.0 \%$ solution) at $75^{\circ} \mathrm{C}$. The coagulum was allowed to settle for $5 \mathrm{~min}$ and the whey was drained through a clean, sterile muslin cloth. Care was taken so that the temperature of whey was maintained above $70^{\circ} \mathrm{C}$. The curd was then collected and transferred to a rectangular shaped sterilized stainless steel hoop $\left(15 \times 10 \times 9 \mathrm{~cm}^{3}\right)$ lined with a clean sterile muslin cloth. The coagulum was pressed for 15-20 min by applying a pressure of 2 to 3 $\mathrm{kg} / \mathrm{cm}^{2}$. The pressed block of paneer were removed from the hoop and immersed in pasteurized chilled water $\left(3\right.$ to $\left.5^{\circ} \mathrm{C}\right)$ for $2 \mathrm{~h}$. The paneer blocks were removed from chilled water placed in a clean stainless steel dish for allowing the water to drain off for $10 \mathrm{~min}$. On completion of draining, paneer blocks were weighed and their representative samples drawn as per method given in IS: 5162 (1969) and subjected to compositional, sensory and rheological evaluation. The products were vacuum packed in the $12 \mu$ polyester $+50 \mu$ LD/LLDPE laminated pouches using a vacuum-packaging machine Make: Saurabh Engg. Ltd., Ahmedabad and stored at $7 \pm 1{ }^{\circ} \mathrm{C}$.

\section{Physico-chemical analysis}

Fat content in milk was estimated by Gerber's method (IS: 1479, Part I, 1960).The total solids of milk was determined by the standard procedure IS: 12333 (1997). The titratable acidity of milk was determined by the method described in the IS: 1479(Part II) (1961). Moisture content in paneer was determined by according to IS: 10484(1983). The fat content of paneer samples was determined by the Mojonnier method as described in IS: 27851979 (Reaffirmed 1995). Protein content in paneer was determined by kjeldahl method as per AOAC (1980), using Kjel-plus digestion system (Model-KPS 006L) and Kjel-plus semi-automatic distillation system (ModelDistil M) of $\mathrm{M} / \mathrm{s}$. Pelican Instruments, Chennai. Ash content of all the samples was 
determined by procedure described in BIS (1981). Titratable acidity of paneer was determined by the procedure as described by Boghra and Rajorhia (1982). pH of paneer was determined as described by O' Keefe et al., (1976) using a Handheld digital $\mathrm{pH}$ meter (Mettler Toledo, Fivego)

\section{Sensory evaluation of paneer}

Each block of paneer was cut into approximately $25 \mathrm{~g}$ rectangular pieces and served in petri dishes which were labelled with three digit codes in randomized order. The paneer samples were tempered to $10 \pm 2^{\circ} \mathrm{C}$ before judging. Sensory analysis of paneer samples was performed in a sensory evaluation laboratory. The sensory panel $(n=10)$ was composed of staff members and post graduate students working in the department. Panellists were selected based on their consistent performance in triangle test. The samples were evaluated using 100 point score card as described in Indian Standards (IS: 15346, 2003).

\section{Statistical analysis}

Completely randomized design (CRD) was used for analysis of data.

\section{Results and Discussion}

\section{Effect of form of lemon rind on quantity of citric acid used and composition of LFP}

Three batches of LFP were prepared lemon rind shred and lemon rind paste were incorporated @ $1.0 \%$ (w/w of milk) and lemon rind powder was incorporated @ 0.5\% (w/w of milk) for manufacture of L1, L2 and L3 respectively.

Table 1 depicts the average quantity of coagulant used in lemon flavoured paneer in terms of gof citric acid $/ \mathrm{kg}$ milk. As seen in
Table 1, the quantity of citric acid used ranged from 1.96 (L1) to $2.15 \mathrm{~g} / \mathrm{kg}$ milk (C). There was non-significant $(\mathrm{P}>0.05)$ difference in quantity of citric acid used amongst all the samples. Quantity of citric acid used in L1, L2, L3 and control were 1.96, 2.09, 2.10 and $2.15 \mathrm{~g} / \mathrm{kg}$ milk respectively. A slightly reduction in quantity of citric used in experimental samples was observed compared to control (C).

As shown in Table 1, the average fat content ranged from $25.40 \%$ (C) to $25.97 \%$ (L1). FDM ranged from $50.01 \%$ (L2) to $54.55 \%$ (C). Moisture content ranged from $48.50 \%$ (L2) to $53.44 \%$ (C). L2 had a least FDM and moisture content from amongst all other samples. It can be seen that different forms of lemon rind had significant effect $(\mathrm{P}<0.05)$ on FDM and moisture content of paneer. No significant $(\mathrm{P}>0.05)$ effect was observed in fat content of paneer. The moisture content of $\mathrm{C}$ was significantly $(\mathrm{P}<0.05)$ higher compared to all other samples. The moisture content of L2 was significantly $(\mathrm{P}<0.05)$ lower compared to all other samples. L2 had a least FDM content from amongst all other samples.

Incorporation of lemon in any form resulted in decrease in moisture content of paneer compared to control. The decrease in moisture content of samples containing lemon rind could be attributed to the higher acidity of samples containing lemon rind compared to control (Table 2). However, the results with respect to moisture are not in accordance with Fernande-Gines et al., (2004) who studied the effect of addition of lemon albedo in bologna sausages and observed that moisture content was affected $(\mathrm{P}<0.05)$ by albedo type and concentrations. The different levels of lemon pulp extract used during preparation of chicken nuggets were found to be significantly affecting the moisture content. The difference in the results could be attributed to water released from the meat 
matrix during the cooking process being retained by albedo, which has a high water holding capacity, due to their soluble compounds, mainly pectin, which may constitute up to $25 \%$ of the Lemon albedo (Meseguer, 2002). Addition of lemon peel did not significantly affect the fat content of samples. Similar results were observed by Rathod (2015) who reported that addition of different levels of lemon pulp extract did not significantly affect the fat in chicken nuggets. Aleson-Carbonell et al., (2005) also observed that the presence of lemon albedo did not modify $(\mathrm{P}>0.05)$ the fat content in the beef burger.

According to FSSAI (2011), paneer shall not contain more than $60.0 \%$ moisture and milk fat content shall not be less than $50.0 \%$ of the dry matter. According to BIS (1983) moisture content in paneer shall be $60.0 \%$ by mass (max) and milk fat content shall be $50.0 \%$ by mass on drymatter basis (min). Therefore, the samples of paneer prepared in the present study fulfilled both the FSSAI and the BIS requirements with respect of fat and moisture content.

\section{Effect of form of lemon rind on $\mathrm{pH}$ and acidity of LFP}

As seen in Table 1, the average $\mathrm{pH}$ values of paneer ranged from 5.30 (L2) to 5.90 (C). The acidity ranged from $0.45 \% \mathrm{LA}(\mathrm{C})$ to $0.72 \%$ LA (L2). L2 had a highest acidity and least $\mathrm{pH}$ content. It can be seen that different forms of lemon rind had significant effect $(\mathrm{P}<0.05)$ on acidity and $\mathrm{pH}$ of paneer. The acidity content of $\mathrm{C}$ was significantly $(\mathrm{P}<0.05)$ lower compared to all other samples. It can be observed that acidity in increasing order was $\mathrm{C}>\mathrm{L} 1>\mathrm{L} 3>\mathrm{L} 2$. The $\mathrm{pH}$ of $\mathrm{C}$ was significantly $(\mathrm{P}<0.05)$ higher compared to all other samples. This decrease in $\mathrm{pH}$ due to lemon albedo could be related to the presence of some organic acid in albedo (Braddock,
1995). Similar results have been reported earlier by Aleson-Carbonell et al., (2005) who found lower $\mathrm{pH}$ values of beef burger added with lemon albedo (at any type and concentration) compared to control samples. Similarly Banerjee et al., (2012) also reported slightly lower $\mathrm{pH}$ (4.90) due to incorporation of in $1.5 \%$ and $2 \%$ broccoli powder extract and lemon albedo in goat meat nuggets.

Effect of forms of lemon rind on fat, protein, TS and its recovery and yield of LFP

The data on average percent recovery of fat, protein, TS and also yield of control as well as LFP affected by incorporation of different forms of lemon rind viz. shreds, paste and powder is presented in Table 2. TS recovery of $\mathrm{C}$ was significantly $(\mathrm{P}<0.05)$ least compared to all other samples. No significant $(\mathrm{P}>0.05)$ effect was observed in fat recovery, protein recovery and yield of LFP.

Higher \% TS recovery observed in L1, L2 and L3 could be due to addition of forms of lemon rind viz. shreds, paste and powder, already contains high amount of TS. Lemon rind forms viz. shreds and paste was added @ $1 \%$ and powder was added @ $0.5 \%$ in LFP. As a result the recovery of total solids in L1 (63.36 $\%)$, L2 (61.23 \%) and L3 (64.07\%) are higher than that of control C $(58.07 \%)$.

\section{Effect of form of lemon rind on sensory attributes}

As shown in Table 3 flavour score of samples varied from 45.13 (C) to 20.13 (L2). The statistical analysis reveals that there was significant difference $(\mathrm{P}<0.05)$ in flavour score among all the samples studied. Amongst all the forms of lemon rind studied L1 i.e. shreds was significantly $(\mathrm{P}<0.05)$ liked the most although it was significantly $(\mathrm{P}<0.05)$ lower than control. The decrease in flavour 
scores of experimental samples was attributed to its bitterness and persistent after taste in samples containing lemon rind. This could be attributed to presence of nomilin, a limonoid that is approximately twice as bitter as limonene (Hashinaga et al., 1977), was found in various citrus species, which is responsible for the bitterness. Amongst all the samples L1 was least bitter. According to BIS grading system for sensory evaluation of paneer (IS 15346, 2003), the flavour score of L1 was greater than $60 \%$ and hence it was felt that there is scope to improve the flavour score by treating the lemon rind with a suitable debittering agent.

With respect to body and texture score L2 scored the least i.e. 25.75. Table 3 reveals that the body and texture scores of control was significantly $(\mathrm{P}<0.05)$ higher than all other samples. The addition of lemon rind powder (L3) had a marginal effect on lowering the body and texture scores of paneer. L3 had a firm, cohesive, slightly spongy body with a smooth texture because the lemon rind powder was distributed uniformly throughout the product. Addition of lemon rind shred (L1) led to an acceptable body and texture, however the paneer had a moist surface. Addition of lemon rind in the form of paste in paneer led to a product with hard body, which was less cohesive and had uneven coarse texture due to the presence of lemon rind paste which did not allow the proper aggregation of casein micelles. Similar results have been reported earlier by Paul et al., (2018) and Buch et al., (2012) who reported that highest score for body and texture was observed in control compared to samples incorporated with basil extract paste and turmeric powder respectively.

The colour and appearance scores for control was significantly $(\mathrm{P}<0.05)$ higher than all other samples. Colour and appearance score of L2 was significantly $(\mathrm{P}<0.05)$ lower than control. The statistical analysis reveals that there was a significant difference $(\mathrm{P}<0.05)$ in colour and appearance score among all the experimental samples studied. This could be because of different forms of lemon rind products affects the colour and appearance of the paneer differently. The control paneer has highest score for colour and appearance, because it does not contain any lemon rind form. Addition of lemon rind in any form of paste and powder resulted in a yellowish tinge to the product. Whereas addition of lemon shreds resulted in uneven appearance which was not liked by panellists. Similar results have been reported earlier by Paul et al., (2018) and Buch et al., (2012) who reported that highest score for colour and appearance was observed control compared to samples incorporated with extract of basil and turmeric respectively.

The total score of L1 was the highest i.e. 69.98 followed by L3 scoring 64.08. The total score of paneer prepared by adding lemon rind shred was higher compare to paneer prepared by using other two forms of lemon rind viz. powder and paste. Addition oflemon rind paste resulted in significant $(\mathrm{P}<0.05)$ reduction in total score of paneer.

L1 was preferred the most with respect to all the attributes studied except colour and appearance score from amongst all the experimental samples. The total score of L1 was significantly $(\mathrm{P}<0.05)$ higher than other experimental samples scoring 68.98 marks which indicates that L1 is of "fair" quality according to BIS (IS 15346, 2003) grading system for paneer. Hence it was selected for use in the remaining part of the study

\section{Selection of suitable type and level of debittering agents}

Five batches of paneer were prepared using different levels of debittering agents viz. D0 
(no debittering agent), D1 ( $\mathrm{ZnSO}_{4} 20 \mathrm{mg} / 100$ $\mathrm{ml}$ of water and $\beta$-cyclodextrin $330 \mathrm{mg} / 100$ $\mathrm{ml}$ of water), D2 $\left(\mathrm{ZnSO}_{4} 30 \mathrm{mg} / 100 \mathrm{ml}\right.$ of water and $\beta$-cyclodextrin $300 \mathrm{mg} / 100 \mathrm{ml}$ of water),D3 ( $\mathrm{ZnSO}_{4} 40 \mathrm{mg} / 100 \mathrm{ml}$ of water and $\beta$-cyclodextrin $250 \mathrm{mg} / 100 \mathrm{ml}$ of water), D4 $\left(\mathrm{ZnSO}_{4} 50 \mathrm{mg} / 100 \mathrm{ml}\right.$ of water and $\beta$ cyclodextrin $100 \mathrm{mg} / 100 \mathrm{ml}$ of water).

Effect of type and level of debittering agents on quantity of citric acid, composition, $\mathrm{pH}$ and acidity of LFP

As shown in Table 4 type and level of debittering agents had significant effect $(\mathrm{P}<0.05)$ on quantity of coagulant used in lemon flavoured paneer. The quantity of coagulant used in control was significantly $(\mathrm{P}<0.05)$ higher compared to all other samples. The quantity of citric acid required to coagulant $1 \mathrm{~kg}$ of milk containing all the levels of debittering agents was lower than control.

\section{Effect of type and level of debittering on compositional attributes of LFP}

As seen in Table 4, the type and level of debittering agents had significant effect $(\mathrm{P}<0.05)$ on moisture and FDM content of paneer. However no significant $(\mathrm{P}>0.05)$ effect was observed in fat content of paneer. The moisture content of D0 was significantly $(\mathrm{P}<0.05)$ higher compared to all other samples. The moisture content of control, D1, D2, D3 and D4were found to be at par $(\mathrm{P}>0.05)$ with each other. The FDM content of D4 was significantly $(\mathrm{P}<0.05)$ lower compared to all other samples. The FDM content of control, D0, D1, and D2were found to be at par $(\mathrm{P}>0.05)$ with each other. $\mathrm{D} 2 \mathrm{had}$ a higher than D4 but lower than D0, D1 and D2. All the samples of paneer prepared in the present study fulfilled both the FSSAI and the BIS requirements for the chemical composition with respect to moisture and fat in dry matter. In this study it was found that all the samples containing lemon peels treated with debittering agents had lower moisture content compared to control. In contrast, Galante et al., (2017) who studied the effect of zinc fortification in soft cheeses reported that the presence of the $\mathrm{Zn}^{2+}$ salts might promote water retention.

The decreased moisture content could be attributed to the higher acidity in samples containing lemon rind (Table 4). Moreover, in studies conducted by Kahraman and Ustunol (2012), the authors postulated that addition of zinc sulphate to cheese milk before clotting contributes to the divalent cation equilibria similarly to the addition of calcium. Divalent cation zinc provides for more bridging between caseins and for more crosslinking similar to calcium. The more rigid protein network that is produced then allows for better fat entrapment into the curd consistent with higher fat content of zinc-fortified cheeses in this study

The results obtained in this study do not agree with those reported by Abd-Rabou (2002, 2010). In their studies, Edam cheese was fortified using different sources of dietary zinc such as zinc acetate, zinc chloride and zinc sulphate at a level of $150 \mathrm{mg}$ zinc / $\mathrm{kg}$ cheese curd. They found no significant difference in moisture content and acidity of cheeses compared to control. However, the results are in agreement with those reported for Zinc-fortified Cheddar cheese containing $228 \mathrm{mg}$ of $\mathrm{zinc} / \mathrm{kg}$ of cheese was manufactured from milk that had $16 \mathrm{mg} / \mathrm{kg}$ food-grade zinc sulphate added. Zinc-fortified cheese had higher protein and slightly higher fat and ash contents, whereas moisture was similar for both cheeses (Kahraman and Ustunol, 2012).

Although not statistically different $(\mathrm{P}>0.05)$, the fat and ash contents of the zinc-fortified 
cheese were higher and moisture content was lower compared with the control cheese. Protein content was significantly higher $(\mathrm{P}<0.05)$ in the zinc-fortified cheeses $(25.39$ $\%)$ compared with the control (24.62\%) (Kahraman and Ustunol, 2012).

\section{Effect of type and level of debittering agents on pH and acidity of LFP}

As seen in Table 4, type and level of debittering agents had significant effect $(\mathrm{P}<0.05)$ on acidity content of paneer. However no significant $(\mathrm{P}>0.05)$ effect was observed in $\mathrm{pH}$ of paneer. The acidity content of D0 was significantly $(\mathrm{P}<0.05)$ lower compared to all other samples.

Effect of type and level of debittering agents on \% fat, protein and TS recovery and yield of LFP

From Table 5, it is clear that no significant $(\mathrm{P}>0.05)$ effect was observed in recovery fat, protein and TS of samples and similarly no significant $(\mathrm{P}>0.05)$ effect was observed in yield of paneer samples.

\section{Influence of type and level of debittering agents on sensory attributes of LFP}

There was significant difference $(\mathrm{P}<0.05)$ in flavour score among all the samples studied. Statistically the flavour score of control was significantly $(\mathrm{P}<0.05)$ higher than all the other samples containing debittering agents. The decrease in flavour scores of experimental samples was due to bitter taste and astringent flavour which persisted and gave a strong bitter after taste.

Amongst the experimental samples the flavour score of D3 and D4 were liked the most. The decreases in flavour scores of other experimental samples are due to less effect of debittering agents. Amongst all the experimental samples D3 and D4 was least bitter and scored $80 \%$ of flavour score (Max. 50). Hence, addition of $40 \mathrm{mg} \mathrm{ZnSO}_{4} / 100 \mathrm{ml}$ of water and $250 \mathrm{mg} \beta$-cyclodextrin $/ 100 \mathrm{ml}$ of water at D3 level and $50 \mathrm{mg} \mathrm{ZnSO}_{4} / 100 \mathrm{ml}$ of water and $100 \mathrm{mg} \beta$-cyclodextrin $/ 100 \mathrm{ml}$ of water at D4 levels resulted in significant reduction in bitterness of LFP.

These results are in accordance with those reported by Keast (2004) who investigated the taste and sensory effect of zinc salts (chloride, iodide, sulphate, bromide, acetate). He reported that Zinc was a potent inhibitor of bitterness $(>70 \%$ reduction in bitter taste), but did not affect salt, savory or sour taste. Zinc may inhibit or alter the taste of foods to which it is added. It has been proposed that taste receptors are composed of amino acids making them susceptible to protein-zinc complexes. Any binding of zinc to taste receptor proteins could change the 3dimensional structure of the receptor, thereby altering the active site of the receptor, rendering it unavailable for normal function (Keast, 2004).

The results are also in agreement with those reported by Abd-Rabou (2002, 2010). In their studies Edam cheese was fortified by different sources of dietary zinc such as zinc acetate, zinc chloride and zinc sulphate at a level of $150 \mathrm{mg}$ zinc / kg cheese curd.

The authors reported that fortified cheeses with zinc salts were scored higher with respect to all sensory attributes, samples were more tasty and had better flavour intensity. Moreover, Edam cheese fortified with zinc acetate had better properties along the ripening period and reached the highest scores earlier than the other treated cheeses or control, except for body and texture properties which were decreased in the last week. 
Table.1 Influence of forms of lemon rind on the quantity of citric acid used, composition, $\mathrm{pH}$ and acidity of LFP

\begin{tabular}{|l|c|c|c|c|c|c|}
\hline \multicolumn{1}{r}{$\begin{array}{c}\text { Type of } \\
\text { Paneer }\end{array}$} & $\begin{array}{c}\text { Quantity of citric } \\
\text { acidused (g/kg milk) }\end{array}$ & \multicolumn{2}{|c|}{ Constituents (\%) } & PH & $\begin{array}{c}\text { Acidity } \\
\text { (\% L.A) }\end{array}$ \\
\hline C & $2.15 \pm 0.15$ & $25.40 \pm 0.58$ & $54.55^{\mathrm{a}} \pm 1.11$ & $53.44^{\mathrm{a}} \pm 1.50$ & $5.90^{\mathrm{a}} \pm 0.29$ & $0.45^{\mathrm{c}} \pm 0.05$ \\
\hline L1 (shred) & $1.96 \pm 0.11$ & $25.97 \pm 0.72$ & $53.02^{\mathrm{ab}} \pm 1.27$ & $51.02^{\mathrm{b}} \pm 0.91$ & $5.48^{\mathrm{b}} \pm 0.22$ & $0.59^{\mathrm{b}} \pm 0.02$ \\
\hline L2 (paste) & $2.09 \pm 0.13$ & $25.76 \pm 1.10$ & $50.01^{\mathrm{c}} \pm 0.83$ & $48.50^{\mathrm{c}} \pm 1.29$ & $5.30^{\mathrm{b}} \pm 0.29$ & $0.72^{\mathrm{a}} \pm 0.02$ \\
\hline $\begin{array}{l}\text { L3 } \\
\text { (powder) }\end{array}$ & $2.12 \pm 0.15$ & $25.78 \pm 0.72$ & $52.51^{\mathrm{b}} \pm 1.72$ & $50.91^{\mathrm{b}} \pm 1.73$ & $5.38^{\mathrm{b}} \pm 0.22$ & $0.67^{\mathrm{a}} \pm 0.04$ \\
\hline CD(0.05) & N S & NS & 1.97 & 2.15 & 0.40 & 0.07 \\
\hline
\end{tabular}

Each observation is a mean \pm SD of four replicate experiments $(n=4)$;

${ }^{\mathrm{a}-\mathrm{c}}$ Superscript letters following numbers in the same column denote significant difference $(\mathrm{P}<0.05)$

Table.2 Influence of forms of lemon rind on the recovery of fat, protein \& total solids and yield of LFP

\begin{tabular}{|c|c|c|c|c|}
\hline Type of paneer & \multicolumn{3}{|c|}{ Percent recovery of constituents } & Yield \\
\cline { 2 - 5 } & Fat & Protein & Total solids & \\
\hline Control & $97.81 \pm 0.79$ & $87.28 \pm 1.81$ & $58.07^{\mathrm{b}} \pm 1.84$ & $\mathbf{1 7 . 3 3} \pm \mathbf{0 . 6 5}$ \\
\hline L1 (shred) & $97.52 \pm 1.51$ & $88.88 \pm 1.81$ & $63.36^{\mathrm{a}} \pm 1.50$ & $\mathbf{1 7 . 0 0} \pm \mathbf{1 . 6 3}$ \\
\hline L2 (paste) & $98.10 \pm 0.56$ & $88.24 \pm 2.42$ & $61.23^{ \pm} \pm 2.54$ & $\mathbf{1 8 . 1 3} \pm \mathbf{0 . 6 7}$ \\
\hline L3 (powder) & $98.16 \pm 1.07$ & $89.10 \pm 2.31$ & $64.07^{\mathrm{a}} \pm 2.04$ & $\mathbf{1 7 . 6 7} \pm \mathbf{1 . 4 4}$ \\
\hline SEm & 0.52 & 1.06 & 1.01 & $\mathbf{0 . 5 9}$ \\
\hline CD $(\mathbf{0 . 0 5})$ & NS & NS & 3.11 & NS \\
\hline CV \% & $\mathbf{1 . 0 7}$ & $\mathbf{2 . 3 9}$ & $\mathbf{3 . 2 7}$ & $\mathbf{6 . 7 7}$ \\
\hline
\end{tabular}

Each observation is a mean \pm SD of four replicate experiments $(n=4)$

${ }^{a-b}$ Superscript letters following numbers in the same column denote significant difference $(\mathrm{P}<0.05)$

Table.3 Average sensory score of LFP incorporated with different forms of lemon rind

\begin{tabular}{|c|c|c|c|c|}
\hline \multirow[t]{2}{*}{ Type of Paneer } & \multicolumn{4}{|c|}{ Sensory score } \\
\hline & $\begin{array}{c}\text { Flavour } \\
(\text { Max.50) }\end{array}$ & $\begin{array}{l}\text { Body and texture } \\
\text { (Max. 35) }\end{array}$ & $\begin{array}{c}\text { Colour and } \\
\text { appearance(Max.10) }\end{array}$ & $\begin{array}{l}\text { Total score* } \\
\text { ( Max.100) }\end{array}$ \\
\hline Control & $45.13^{\mathrm{a}} \pm 1.97$ & $32.00^{\mathrm{a}} \pm 0.81$ & $8.65^{a} \pm 0.12$ & $90.78^{a} \pm 0.045$ \\
\hline L1 (shred) & $30.13^{b} \pm 1.39$ & $27.50^{\mathrm{b}} \pm 1.29$ & $7.35^{c} \pm 0.23$ & $69.98^{b} \pm 0.64$ \\
\hline L2 (paste) & $20.13^{\mathrm{d}} \pm 1.26$ & $25.75^{c} \pm 0.95$ & $7.85^{\mathrm{b}} \pm 0.12$ & $58.73^{d} \pm 0.73$ \\
\hline L3 (powder) & $22.88^{c} \pm 1.32$ & $28.75^{b} \pm 0.95$ & $7.45^{c} \pm 0.12$ & $64.08^{c} \pm 0.77$ \\
\hline SEm & 0.76 & 0.51 & 0.08 & $0 . \overline{31}$ \\
\hline CD (0.05) & 2.34 & 1.57 & 0.25 & 0.95 \\
\hline CV \% & 5.13 & 3.58 & 2.09 & 0.87 \\
\hline
\end{tabular}

* Full marks has been allotted to packaging i.e 5/5

Each observation is a mean \pm SD of four replicate experiments $(n=4)$;

${ }^{\text {a-d }}$ Superscript letters following numbers in the same column denote significant difference $(\mathrm{P}<0.05)$ 
Table.4 Influence of type and level of debittering agents on quantity of citric acid used, composition, $\mathrm{pH}$ and acidity of LFP

\begin{tabular}{|c|c|c|c|c|c|c|}
\hline \multirow{2}{*}{$\begin{array}{c}\text { Type and level } \\
\text { of debittering } \\
\text { agents }\end{array}$} & \multirow{2}{*}{$\begin{array}{c}\text { Quantity of } \\
\text { citric } \\
\text { acidused (g/kg } \\
\text { milk) }\end{array}$} & \multicolumn{3}{|c|}{ Constituents (\%) } & \multirow[t]{2}{*}{$\mathbf{P H}$} & \multirow{2}{*}{$\begin{array}{l}\text { Acidity } \\
\text { (\% L.A) }\end{array}$} \\
\hline & & Fat & FDM & Moisture & & \\
\hline D0 & $2.15^{\mathrm{a}} \pm 0.18$ & $25.91 \pm 1.76$ & $55.91^{a} \pm 0.63$ & $53.66^{\mathrm{a}} \pm 2.06$ & $5.90 \pm 0.29$ & $0.46^{c} \pm 0.04$ \\
\hline D1 & $1.95^{\mathrm{b}} \pm 0.15$ & $26.98+1.24$ & $55.30^{\mathrm{a}} \pm 1.26$ & $51.22^{b} \pm 0.97$ & $5.60 \pm 0.21$ & $0.56^{\mathrm{ab}} \pm 0.04$ \\
\hline D2 & $1.85^{\mathrm{b}} \pm 0.03$ & $27.30 \pm 0.95$ & $55.74^{a} \pm 1.43$ & $51.03^{b} \pm 1.46$ & $5.50 \pm 0.21$ & $0.59^{\mathrm{a}} \pm 0.03$ \\
\hline D3 & $1.88^{\mathrm{b}} \pm 0.01$ & $26.15 \pm 1.54$ & $52.31^{\mathrm{b}} \pm 1.24$ & $50.01^{\mathrm{b}} \pm 1.52$ & $5.30 \pm 0.21$ & $0.60^{\mathrm{a}} \pm 0.04$ \\
\hline D4 & $1.85^{\mathrm{b}} \pm 0.04$ & $25.34 \pm 1.30$ & $50.42^{c} \pm 1.17$ & $49.75^{\mathrm{b}} \pm 1.24$ & $5.70 \pm 0.32$ & $0.53^{\mathrm{b}} \pm 0.03$ \\
\hline SEM & 0.06 & 0.69 & $0 . \overline{59}$ & $0 . \overline{75}$ & 0.13 & 0.02 \\
\hline $\mathrm{CD}(0.05)$ & 0.17 & NS & 1.78 & 2.26 & NS & 0.05 \\
\hline $\mathrm{CV} \%$ & 5.71 & 5.28 & 2.20 & 2.93 & 4.55 & 6.24 \\
\hline
\end{tabular}

Each observation is a mean \pm SD of four replicate experiments $(n=4)$

${ }^{\mathrm{a}-\mathrm{c}}$ Superscript letters following numbers in the same column denote significant difference $(\mathrm{P}<0.05)$

Table.5 Influence of type and level of debittering agents on recovery of fat, protein and total solids and yield of LFP

\begin{tabular}{|c|c|c|c|c|}
\hline \multirow{2}{*}{$\begin{array}{l}\text { Type and level of } \\
\text { debittering agents }\end{array}$} & \multicolumn{3}{|c|}{ Percent recovery of constituents } & \multirow[t]{2}{*}{ Yield (\%) } \\
\hline & Fat & Protein & Total solids & \\
\hline D0 & $97.91 \pm 0.85$ & $87.30 \pm 1.33$ & $58.03 \pm 2.10$ & $17.33 \pm 1.26$ \\
\hline D1 & $97.87 \pm 0.76$ & $87.54+0.96$ & $58.93 \pm 1.02$ & $18.30 \pm 0.49$ \\
\hline D2 & $97.84 \pm 1.41$ & $87.35 \pm 1.49$ & $58.30 \pm 0.87$ & $18.00 \pm 1.42$ \\
\hline D3 & $97.89 \pm 0.79$ & $87.58 \pm 0.95$ & $59.07 \pm 1.39$ & $18.20 \pm 0.91$ \\
\hline D4 & $97.86 \pm 1.40$ & $87.45 \pm 2.05$ & $58.65 \pm 1.73$ & $18.28 \pm 0.71$ \\
\hline SEm & $0 . \overline{54}$ & $0 . \overline{72}$ & $0 . \overline{75}$ & $0 . \overline{51}$ \\
\hline CD (0.05) & NS & NS & NS & NS \\
\hline CV \% & 1.11 & 1.65 & 2.55 & 6.14 \\
\hline
\end{tabular}

Each observation is a mean \pm SD of four replicate experiments $(n=4)$

Table.6 Influence of type and level of debittering agents on sensory score of LFP

\begin{tabular}{|c|c|c|c|c|}
\hline \multirow{2}{*}{$\begin{array}{l}\text { Type and level of } \\
\text { debittering agents }\end{array}$} & \multicolumn{4}{|c|}{ Sensory score } \\
\hline & $\begin{array}{l}\text { Flavour } \\
\text { (Max. 50) }\end{array}$ & $\begin{array}{l}\text { Body and texture } \\
\text { (Max. 35) }\end{array}$ & $\begin{array}{c}\text { Colour and appearance } \\
\text { (Max. 10) }\end{array}$ & $\begin{array}{c}\text { Total score* } \\
\text { (Max. 100) }\end{array}$ \\
\hline D0 & $45.50^{\mathrm{a}} \pm 0.54$ & $32.10^{\mathrm{a}} \pm 1.82$ & $8.70 \pm 0.23$ & $91.30^{\mathrm{a}} \pm 2.34$ \\
\hline D1 & $36.25^{\mathrm{c}} \pm 1.81$ & $26.00^{c} \pm 1.63$ & $8.25 \pm 0.65$ & $75.50^{d} \pm 1.47$ \\
\hline D2 & $38.05^{c} \pm 2.09$ & $24.25^{c} \pm 0.88$ & $8.15 \pm 1.10$ & $75.45^{d} \pm 1.66$ \\
\hline D3 & $40.15^{b} \pm 1.53$ & $27.95^{\mathrm{b}} \pm 0.84$ & $8.50 \pm 0.74$ & $81.60^{b} \pm 1.97$ \\
\hline D4 & $40.96^{b} \pm 2.86$ & $25.41^{c} \pm 0.67$ & $7.50 \pm 0.61$ & $78.87^{c} \pm 1.12$ \\
\hline SEm & 0.96 & 0.63 & 0.36 & 0.88 \\
\hline CD (0.05) & 2.90 & 1.90 & NS & 2.65 \\
\hline CV \% & 4.78 & 4.64 & 8.76 & 2.19 \\
\hline
\end{tabular}

* Full marks has been allotted to packaging i.e. $5 / 5$

Each observation is a mean \pm SD of four replicate experiments $(n=4)$;

${ }^{\mathrm{a}-\mathrm{d}}$ Superscript letters following numbers in the same column denote significant difference $(\mathrm{P}<0.05)$ 
Table 6 shows that the body and texture scores for control (D0) was significantly higher than all other samples. The samples were criticized by panellists for their hard body, this could be attributed to presence of fiber in lemon rind and cations such as $\mathrm{Zn}^{++}$because of treated with zinc sulphate, which could have resulted in closer linkages of protein resulting in increased hardness.

The results obtained in this study are somewhat similar to those reported by Kahraman and Ustunol (2012), who reported that although zinc-fortified cheese was harder as determined by the texture analyzer, the untrained consumer panel did not detect differences in the sensory attributes and overall quality of the cheeses. However, in our studies, panellist reported that samples treated with $\mathrm{ZnSo} 4$ were harder than control. These authors hypothesized that the addition of zinc sulphate to cheese milk before clotting contributes to the divalent cation equilibria similarly to the addition of calcium. Divalent cation zinc provides for more bridging between caseins and for more crosslinking similar to calcium. The more rigid protein network that is produced then allows for better fat entrapment into the curd consistent with higher fat content of zinc-fortified cheeses in this study (Kahraman and Ustunol, 2012).

The results obtained in this study are in contrast to studies conducted by Galante et al., (2017) who prepared Cuartirolo cheese which is a soft cheese defined by the Código Alimetario Argentino as a high (46-55\%) or very high $(>55 \%)$ moisture, fatty $(45-60 \%)$, manufactured with raw milk, acidified by lactic cultures and coagulated by rennet or specific enzymes (ANMAT, 2002). In their studies, $\mathrm{Zn}^{2+}$ salts (16 mg $\mathrm{Zn}^{2+} \mathrm{kg}-1$ ) were added in fortified cheese samples. They reported that $\mathrm{Zn}^{2+}$ salt fortification did not have an effect on firmness value. They were of the opinion that the $\mathrm{Zn}^{2+}$ concentrations added seems not to affect the establishment of rearrangements that lead to increase in the coagulum firmness. These results do not agree with the observation of a soft and brittle curd during cheese manufacture from $\beta-C D$ treated cream base which was used for manufacture of Cuartirolo soft cheese (Galante et al., 2017). Kwak et al., (2002) also reported similar results for cholesterol-reduced Cheddar cheese manufacture treated with $\beta$ CD.

D0 and D3 were significantly $(\mathrm{P}<0.05)$ higher colour and appearance score than the other experimental samples viz. D1, D2 and D4. The total score of D4 was significantly $(\mathrm{P}<0.05)$ higher than $\mathrm{D} 1, \mathrm{D} 2$ but lower than $\mathrm{C}$ and D3. D1 and D2 were found be at par $(\mathrm{P}>0.05)$ with each other. The overall preference of samples were in the order D0> D3> D4> D1> D2.

D3and D4 was preferred the most with respect to all the attributes studied from amongst all the experimental samples. The total scores of D3 was significantly $(\mathrm{P}<0.05)$ higher than other experimental samples scoring 81.60 marks which indicates that D3 is of good quality according to BIS grading system for paneer. Treatment of lemon rind

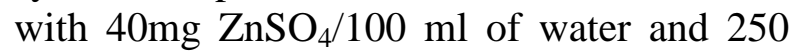
mg $\beta$-cyclodextrin $/ 100 \mathrm{ml}$ of water at D3 level resulted in significant reduction in bitterness of LFP.

In conclusion the debittering of lemon rind shreds with $40 \mathrm{mg} \mathrm{ZnSO}_{4} / 100 \mathrm{ml}$ of water and $250 \mathrm{mg} \beta$-cyclodextrin $/ 100 \mathrm{ml}$ of water at D3 level resulted in significant reduction in bitterness of LFP without affecting compositional attributes of paneer.

\section{References}

Abd-Rabou NS (2002) Effect of dietary zinc fortification on quality of Domiati cheese. 
Egyptian J Dairy Sci 30(2): 201-216.

Abd-Rabou NS, Zaghloul AH, Seleet FL, El-Hofi MA (2010) Properties of Edam cheese fortified by dietary zinc salts. J American Sci 6(10): 441-446.

Aleson-Carbonell L, Fernandez-Lopez J, PerezAlvarez JA, Kuri V (2005) Characteristics of beef burger as influenced by various types of lemon albedo. Innov Food Sci Emerg Technol 6(2): 247-255.

ANMAT (2002) Código Alimentario Argentino. Capítulo VIII: Alimentos lácteos. Buenos Aires: De la Canal y Asociados.

AOAC (1980) Official's methods of analysis. Association of Official Analytical Chemists, Washington DC, pp. 272-274.

Aronson JK (2001) Nature Publishing Group. Retrieved from: http:// medicine. nature.com.

Banerjee R, Verma AK, Das AK, Rajkumar V, Shewalkar AA, Narkhede HP (2012) Antioxidant effects of broccoli powder extract in goat meat nuggets. Meat Sci 91(2):179-184.

BIS (1981) Handbook of Food analysis, Dairy Products (BIS: Part XI). Indian Standards Institution, Manak Bhavan, New Delhi.

BIS (1983) Bureau of Indian Standards, IS 10484. Specification for paneer. Manak Bhawan, New Delhi.

Boghara VR, Rajorhia GS (1982) Chemical quality of some marketed indigenous milk products - I. Major constituents and mineral composition of paneer. J Food Sci Technol 28: 57-68.

Braddock RJ (1995) By-products of citrus fruits. Food Technol 49: 74-77.

Buch S, Pinto S, Aparnathi KD (2014) Evaluation of efficacy of turmeric as a preservative in paneer. J Food Sci Technol 51(11): 32263234.

Dias HMAM, Berbicz F, Pedrochi F, Baesso ML, Matioli G (2010) Butter cholesterol removal using different complexation methods with beta-cyclodextrin, and the contribution of photoacoustic spectroscopy to the evaluation of the complex. Food Res Int 43(4): 1104-1110.

Fernandez-Gines JM, Fernandez-Lopez J, SayasBarbera E, Sendra E, Perez-Alvarez JA (2004) Lemon albedo as a new source of dietary fiber: Application to bologna sausages. Meat Sci 67: 7-13.

FSSAI (2011) Food Safety and Standards Authority of India. Ministry of health and family welfare. Government of India.

Galante M, Pavon Y, Lazzaroni S, Soazo M, Costa S, Boeris V, Rozycki S (2017) Effect of cholesterol- reduced and zinc fortification treatments on physicochemical, functional, textural, microstructural and sensory properties of soft cheese. Int J Dairy Technol 70(4): 533-541.

Hargitt B (2006) Introduction in Carbonated Soft Drinks, Formulation and Manufacture. In Ashurst, P. R., Eds. Blackwell Publishing Ltd: Oxford, 1-14.

Hashinaga $F$, Ejima $\mathrm{H}$, Nagahama $\mathrm{H}$, Itoo $\mathrm{S}$ (1977) Studies on the limonoids in citrus fruits. I. Seasonal changes of limonoid components in Ponkan, Tankan, Early satsuma mandarin and Natsudaidai fruits. Bulletin 27(3): 171-180.

IS: 10484 (1983) Specification for Paneer. Bureau of Indian Standards, Manak Bhavan, New Delhi 1-11.

IS: 12333 (1997) Milk, Cream and Evaporated milk-Determination of total Solids Content (reference method). Bureau of Indian Standards, Manak Bhavan, New Delhi.

IS: 1479 (Part I) (1960) Methods of test for dairy industry-Rapid examination of milk. Bureau of Indian Standards, Manak Bhavan, New Delhi

IS: 1479 (Part II) (1961) Methods of test for dairy industry-Rapid examination of milk. Bureau of Indian Standards, Manak Bhavan, New Delhi

IS: 2785-1979 (Reaffirmed 1995) Specification for Natural cheese (Hard Variety), Processed Cheese, Processed Cheese Spread and Soft Cheese. Bureau of Indian Standards, Manak Bhavan, New Delhi.

IS: 5162 (1969) Specification for paneer. Bureau of Indian Standards, Manak Bhavan, New Delhi.

IS: 15346 (2003) Method for Sensory Evaluation of Paneer/Chhana [FAD 19: Dairy Products and Equipment] Indian Standard Institution, New Delhi

Kahraman O, Ustunol Z (2012) Effect of zinc 
fortification on Cheddar cheese quality. $\mathrm{J}$ Dairy Sci 95: 2840-2847.

Keast RS (2003) The effect of zinc on human taste perception. J Food Sci 68(5): 18711877.

Keast RS (2008) Modification of the bitterness of caffeine. Food Qual Prefer 19(5): 465-472.

Keast RS, Breslin PA (2005) Bitterness suppression with zinc sulphate and $\mathrm{Na}$ cyclamate: a model of combined peripheral and central neural approaches to flavour modification. Pharm Res 22(11): 1970-1977.

Keast RS, Canty TM, Breslin PA (2004) Oral zinc sulphate solutions inhibit sweet taste perception. Chem Senses 29(6): 513-521.

Kwak HS, Jung CS, Shim SY, Ahn J (2002) Removal of cholesterol from Cheddar cheese by $\beta$-cyclodextrin. JAgric Food Chem 50(25): 7293-7298.

Linde GA, Junior AL, De Faria EV, Colauto NB, de Moraes FF, Zanin GM (2010) The use of $2 \mathrm{D}$ NMR to study $\beta$-cyclodextrin complexation and debittering of amino acids and peptides. Food Res Int 43(1): 187-192.

Marin FR, Frutos MJ, Perez-Alvarez JA, Martinez-Sanchez F, Del Rio JA (2002) Flavonoids as nutraceuticals: structural related antioxidant properties and their role on ascorbic acid preservation. In Studies in Natural Products Chemistry (Vol 26, pp. 741-778). Elsevier.

Meseguer A (2002) Caracterización de subproductos de las industrias de elaboración de zumos citricos (Doctoral dissertation, BS thesis. Universidad Miguel Hernández (Orihuela). Alicante, Spain).

O'Keefe RB, Fox PF, Daly C (1976) Contribution of rennet and starter proteases to proteolysis in Cheddar cheese. J Dairy Res 43(1): 97-107.

Paul V, Kushwaha P, Paul A (2018) Enrichment of low fat paneer by incorporating herbal extracts (Basil, Ginger and Mint). Pharma Innov J 7(7): 472-476.

Pomastowski P, Sprynskyy M, Buszewski B (2014) The study of zinc ions binding to casein. Colloids Surf B 120, 21-27.

Rathod KR (2015) Utilization of Lemon Peel and Pulp Extract as Natural Antioxidants in Chicken Nuggets (Doctoral dissertation, MAFSU).

Rescifina A, Chiacchio U, Iannazzo D, Piperno A, Romeo G (2010) $\beta$-cyclodextrin and caffeine complexes with natural polyphenols from olive and olive oils: NMR, thermodynamic, and molecular modeling studies. J Agric Food Chem 58(22), 11876-11882.

Salgueiro MJ, Zubillaga M, Lysionek A, Caro R, Weill R, Boccio J (2002) Fortification strategies to combat zinc and iron deficiency. Nutri Rev 60(2): 52-58.

Shaw PE (1990) Cyclodextran polymers in removal of bitter compounds in citrus juices. In: Rouseff $\mathrm{R}$ (ed) Bitterness in foods and beverages. Elsevier, New York, 309-324.

Dilas S, CanadanoviC-Brunet J, Cetkovic G (2009) By-products of fruits processing as a source of phytochemicals. Chem Ind Chem Eng Q 15(4): 191-202.

Tamamoto LC, Schmidt SJ, Lee SY (2010) Sensory properties of ginseng solutions modified by masking agents. J Food Sci 75(7): 341-347.

\section{How to cite this article:}

Yashavantha, R., Suneeta Pinto, Dasharath Patel, Preeti Paul and Mamata Chaudhary. 2020. Influence of Debittered Lemon Rind on Quality of Lemon Flavoured Paneer. Int.J.Curr.Microbiol.App.Sci. 9(09): 1522-1535. doi: https://doi.org/10.20546/ijcmas.2020.909.193 